DOI: $10.17516 / 1997-1370-0654$

УДК 005.334.2

\title{
Professional and Ethical Standards in the Activity of a Mediator: Problems of Implementation and Control
}

\author{
Anastasiya S. Arkhipkina* \\ East Siberian Branch of the Russian Academy of Justice \\ Irkutsk, Russian Federation \\ "Baikal Mediators League" Association \\ Irkutsk, Russian Federation
}

Received 20.05.2020, received in revised form 01.09.2020, accepted 07.09.2020

\begin{abstract}
The article examines the professional and ethical standards of a mediator in Russia. Using methods of the formal legal analysis and the comparative legal method, the author reveals the requirements of the professional standard for the knowledge, skills and abilities of mediator who carry out their activities on a professional basis. The main ethical standards enshrined in the European Code of Conduct for Mediators and the Code of Russian Mediators are analysed. The article also reveals the main problems of implementation of professional and ethical standards, as well as control over their observance. The experience of foreign countries in establishing the specified standards and control systems is presented.
\end{abstract}

Keywords: mediation, professional standard of mediator's activity, code of professional ethics of a mediator.

Research area: civil procedure, arbitration procedure.

Citation: Arkhipkina, A.S. (2020). Professional and ethical standards in the activity of a mediator: problems of implementation and control. J. Sib. Fed. Univ. Humanit. Soc. Sci., 13(9), 1435-1448. DOI: $10.17516 / 1997-1370-0654$.

(C) Siberian Federal University. All rights reserved

* Corresponding author E-mail address: nsakharova@yandex.ru ORCID: 0000-0003-4772-8974 


\section{Introduction into the problem}

The Federal Law No. 193-FZ of July 27, 2010 "On an alternative procedure of dispute resolution with participation of a mediator (mediation procedure)"1 laid the foundation for the widespread development of mediation practice for resolving disputes and the formation of a new social and legal institution mediation. The legislator substantiated the need to develop mediation in its role to improve the judicial and legal systems, reduce corruption-generating factors, harmonize business relations, and reduce conflicts in society. The need for widespread introduction of mediation in various fields was also highlighted by various conceptual and strategic documents adopted in the second decade of the $21^{\text {st }}$ century, in particular: The Russian Financial Market Development Strategy until 2020 , approved by the order of the Government of the Russian Federation on February 29, 2008, No. 2043-r; the Russian Insurance Activity Development Strategy until 2020, approved by the order of the Government of the Russian Federation on July 22, 2013, No. 1293-r; the plan of priority measures for the implementation of the "2012-2017 National Children's Interests Action Strategy," approved by the Government of the Russian Federation on October 15, 2012, which provides for the creation of school mediation services in educational organizations, as well as the development of a network of mediation services in order to implement restorative justice; The state program "Justice" approved by the order of the Government of the Russian Federation on April 4, 2013, No. 517-r, which considers mediation in enforcement proceedings, as well as in the activities of notaries. These and other documents created the preconditions and legal basis for the formation of a new type of activity - mediation in the settlement of disputes. On December 15, 2014, by the order of the Ministry of Labour and Social Protection of the Russian Federation, the professional standard "The

\footnotetext{
On an alternative procedure of dispute resolution with participation of a mediator (mediation procedure): Federal Law of July 27, 2010 No.193-FZ (2010). In Rossiiskaia Gazeta, July, 30.
}

expert in the field of mediation (mediator)" was approved. ${ }^{2}$

It should be noted that the main definitions and requirements for the procedure and the mediator are contained in the already mentioned law "On an alternative procedure of dispute resolution with participation of a mediator (mediation procedure)." So, in accordance with Art. 2 of the law, a mediation procedure is a way of settling disputes with the assistance of a mediator on the basis of the voluntary consent of the parties in order to achieve a mutually acceptable solution; a mediator, mediators are an independent individual, independent individuals, involved by the parties as mediators in the settlement of a dispute to assist in the development of a solution by the parties. We believe that these formulations do not fully reflect the features and specifics of both the mediation procedure and the figure of a mediator, which requires a more detailed study of the basic requirements and standards for professional mediators based on the study of the works of Russian and foreign authors, in particular O.V. Allakhverdova, N.I. Gaidaenko-Sher, Ts.A. Shamlikashvili, D.G. Koroviakovskii, S.K. Zagainova, Bessemer and others, and the analysis of Russian and foreign legislation. The purpose of the study is to form an idea of mediation as a type of professional activity, analyse the problems of implementation of professional and ethical standards of the mediator's activity, and propose ways to solve them. The research uses the method of formal legal analysis and the comparative legal method.

\section{Professional standards of mediator's activity}

Speaking about professional standards in mediation, one should speak, first of all, about the general requirements for a mediator, which are enshrined in the legislation. Thus, in accordance with the Article 16 of the Law on Mediation, persons who have reached the age of twenty-five, have a higher education and have

\footnotetext{
2 On approval of the Professional Standard "The expert in the field of mediation (mediator)": order of the Ministry of Labour and Social Protection Russian Federation of January 15, 2014 No. 1041n (2010). In Biulleten' normativnykh aktov federal'nykh organov ispolnitel'noi vlasti, July, 27.
} 
received additional professional education on the application of the mediation procedure, can carry out the activities of mediators on a professional basis. Also, the activities of mediators on a professional basis can be carried out by retired judges.

A mediator is not entitled to:

1) be a representative of any party;

2) provide any party with legal, consulting or other assistance;

3) carry out the activities of a mediator if, during the mediation procedure, he is personally (directly or indirectly) interested in its result, including being in a family relationship with a person who is one of the parties;

4) make public statements on the merits of the dispute without the consent of the parties.

Mediators may not be persons holding government positions in the Russian Federation, government positions in the constituent entities of the Russian Federation, government civil service positions, municipal service positions, unless otherwise provided by federal laws.

Thus, a legislator makes a number of requirements for a mediator, which can be divided into the following groups: age requirements; educational requirements; requirements related to restrictions on engaging in this type of activity. Requirements for the qualifications of a mediator, i.e. his knowledge, skills and abilities necessary for the implementation of this type of activity are contained in the professional standard "The expert in the field of mediation (mediator)," approved by the Order of the Ministry of Labour and Social Protection of the Russian Federation of December 15, 2014 No. 1041 (as amended on December 12, 2016). In accordance with the standard, the main goal of professional activity is the settlement of disputes using a mediation procedure with the participation of an independent person - a mediator as an intermediary. This type of activity is attributed to two groups of occupations: 2429 - specialists in the field of law, not included in other groups; 2446 - specialists in the field of social professions not included in other groups. The professional standard identifies three generalized labour functions, each of which imposes separate requirements for education and training, practi- cal work experience, knowledge and skills, and may also contain special conditions for admission to work. Let us note that all generalized labour functions correspond to the highest levels of qualifications - the sixth and the seventh, which complies with the qualifications of heads of departments, organizations and enterprises. The generalized labour function "Conducting a mediation procedure (without specialization)" consists of the following labour functions: 1) organizational, technical and documentary support of the mediation procedure; 2) preparation for the mediation procedure; 3 ) conducting the process of developing the terms of the mediation agreement and completing the mediation procedure. The labour function "Organizational, technical and documentary support of the mediation procedure" involves the following labour actions: a) explaining the essence of the mediation procedure to the parties and their consultants in general; b) identifying the essence of the dispute in order to understand its suitability for resolution within the framework of the mediation procedure; c) establishing the legal personality of persons presupposing the participation in the mediation procedure; $d$ ) agreeing on the candidacy of a mediator for a specific mediation procedure; e) coordinating organizational issues related to the mediation procedure; f) coordinating financial costs for the mediation procedure; g) making draft documents used in the preparation, organization and conduction of the mediation procedure and upon its completion; h) coordinating draft documents used in the preparation, organization, conduction of the mediation procedure and upon its completion with the parties of the mediation procedure. To perform these labour actions, the mediator must be able to: assess the applicability of mediation for a specific case/ dispute, carry out professional interaction with the participants in the mediation procedure, establish the powers of the persons participating in the mediation procedure, calculate and justify the financial costs of the mediation procedure, draw up organizational, administrative and reference documents, use office equipment (computer, printer, scanner, fax), use basic office programmes (word processing and presentation programmes). The mediator must have 
knowledge of the principles of mediation, the sequence of the mediation procedure, the role of the mediator and participants in the mediation procedure, and the expenditure items for the mediation procedure. The mediator must know the Code of Professional Ethics of the Mediator, the basics of the civil law, the legislation of the Russian Federation on mediation, the basics of social communication, the rules for drafting and maintaining organizational, administrative and reference documents, restrictions, social norms and standards, traditions, customs and their role in resolving conflicts, specifics of the use of basic office programmes (text editors and presentation programmes).

The labour function "Preparing for the mediation procedure" provides for the performance of such labour actions as: a) explaining to the parties the essence of the mediation procedure; b) identifying the expectations of the parties regarding the mediation procedure; c) forming and coordinating the rules for conducting a specific mediation procedure; d) forming and coordinating the temporary regulations for a specific mediation procedure. To do this, the mediator needs to be able to establish interaction with each of the parties and participants in the mediation procedure, establish interaction between the parties and participants in the procedure, analyse information, formulate, clarify, explain the statements of participants and parties in the mediation procedure, generalize and summarize the statements of the participants, assist the parties in the analysis of the benefits, costs, consequences and possibilities of events/ states, recognize and correct the emotional state of the participants in the mediation procedure, structure the goals of the participants in the mediation procedure, organize the process of interaction between the participants in the mediation procedure, maintain a balance of time and forces in the process of defending points of view of the parties, maintain neutrality, impartiality in relation to the parties and the subject of the dispute. The necessary knowledge for the performance of this labour function is knowledge about the principles of mediation, the sequence of the mediation procedure, techniques for providing mediation assistance and types of emotional responses. A mediator must know the Code of Professional Ethics of a Mediator, the basics of the civil law, the legislation of the Russian Federation on mediation, the basics of social psychology, the basics of humanistic psychology, the basics of cognitive psychology, the basics of psychological correction of attitudes and perception.

The third function "Maintaining the process of developing the terms of the mediation agreement and completing the mediation procedure" includes the following labour actions: a) clarifying the content of the dispute between the parties to the mediation procedure; b) identifying issues that have arisen in connection with the dispute and require discussion during the mediation procedure; c) forming an agenda for the discussion of issues requiring consideration during the mediation procedure; d) holding a discussion of issues on the agenda in order to ensure that the parties understand the procedure of mediation of their interests and the interests of the other party; e) identifying the true needs of the parties, including regarding the result of the mediation procedure; f) developing options for resolving the dispute following the discussion of issues on the adopted agenda; g) discussing with the parties the procedure of mediation of the feasibility of the mediation agreement; $h$ ) agreeing with the parties on the procedure of mediation of the algorithm for fulfilling the mediation agreement; i) coordinating actions of the parties to the mediation procedure in case of failure by them or one of the parties to fulfil the mediation agreement; j) drawing up and ensuring the signing of the final mediation agreement; k) identifying the attitude of the parties to the course and results of the mediation procedure.

Within the framework of this labour function, the mediator must be able to analyse information, formulate, clarify, explain the statements of the participants and parties to the mediation agreement, generalize and summarize the statements, analyse the benefits, costs, consequences and possibilities of events/ conditions, recognize and correct the emotional state of the participants in the mediation procedure, structure the goals of the participants in the mediation procedure, organize the process of interaction between the participants in 
the mediation procedure, maintain neutrality, impartiality with respect to the parties and the subject of the dispute, highlight the essential in the statements, analyse the emotional reactions of the parties, organize the search for joint solutions, facilitate the critical constructive analysis, facilitate the formulation of decisions, maintain the balance of time and forces between the parties, ensure the optimal level of specification of decisions, work with information visualization tools. To do this, a mediator needs knowledge about the principles of mediation, the sequence of the mediation procedure, techniques of the mediator's work, types of emotional responses, the basics of humanistic and cognitive psychology, the basics of the civil law, the legislation of the Russian Federation on mediation, the basics of negotiations, the basics of formal logic, the basics of psychological adjustment of attitudes and perception, types of emotional responses, basic techniques and means of information visualization, ways of finding joint solutions, the Code of Professional Ethics of Mediators.

A general mediator (this is the name of the position of a person performing the generalized labour function "Conducting the mediation procedure") must have a higher education bachelor's degree, and additional professional education under advanced training programmes in the field of mediation. A special condition for admission to work is reaching the age of 25 years.

The generalized labour function "Conducting the mediation procedure in a specialized field" includes the following labour functions: 1. Preparation for the mediation procedure in a specialized field; 2 . Maintaining the process of developing, agreeing on the terms of a mediation agreement and completing the mediation procedure on a dispute in a specialized field.

In accordance with the explanatory note to the professional standard under consideration, the allocation of an independent generalized labour function, which characterizes the activity during the mediation procedure in a specialized field, was due to the fact that in order to perform this activity, in contrast to the activity of a general mediator, it is necessary to possess more complex skills and knowledge (special techniques and knowledge of conducting mediation procedures in accordance with a specialized field). At the same time, the developers emphasize that the concept of a specialized sphere includes different types of mediation: commercial mediation, family mediation, mediation in the field of education, mediation in resolving labour disputes, in restorative justice, etc. The labour functions "Preparing for the mediation procedure in a specialized field" and "Maintaining the process of developing, agreeing on the terms of a mediation agreement and completing the mediation procedure on a dispute in a specialized field" includes labour actions similar to labour actions within these labour functions of the generalized labour function "Maintaining the procedure mediation without specialization." However, it requires additional knowledge, skills and abilities from the mediator. In particular, a mediator must have subject knowledge in a specialized field, know, in addition to the basics of civil law, the foundations of the family and labour law, know and apply special techniques for conducting mediation in accordance with a specialized field. A mediator in a specialized field must have a higher education at the level of a specialist or a master's degree, and additional education under advanced training programmes in the field of mediation. The professional standard sets requirements for practical experience - at least two years in the field of specialization, as well as for age - at least 25 years old. Thus, we can conclude that higher requirements are imposed on a mediator in a specialized field, and basic knowledge and skills are insufficient for this position.

The professional standard includes a generalized labour function "Supervision in the specialized field of mediation," which contains the following labour functions:

1. Analysis of practical cases of an expert in the specialized field of mediation.

2. Review, analysis and correction of professional skills of an expert in the specialized field of mediation.

3. Development of skills of the professional self-analysis of an expert in the specialized field of mediation. 
A supervisor can be a person who has a higher education at the level of a specialist or a master's degree, as well as completed additional professional advanced training programmes in the field of mediation in specialized fields, with experience in mediation (conducting mediation procedures) of at least seven years, with not less than three years of working in a specialized field.

The institution of supervision is formed primarily in psychological counselling. The term "supervision" comes from Latin supervidere - to view from above. Supervision is one of the methods of theoretical and practical advanced training of specialists in the field of psychotherapy, clinical psychology, and others in the form of their professional counselling and analysis of the feasibility and quality of the practical approaches and methods of psychotherapy (Kulakov, 2004: 2).

In the future, supervision is moving into other professions related to counselling. The purpose of supervision is to broaden the supervisee's awareness and protect the interests of a client. Supervision tasks are the professional and personal development of a consultant, the development of special skills and abilities that will make it possible to assess the results of work, the increase in the level of responsibility in counselling. Supervision helps the consultant to understand himself and the counselling process, to perfectly master the knowledge and skills necessary in the work. It contributes to the improvement of the professional activity of a specialist. In the process of supervision, a specialist gets the opportunity to realize and integrate his personal ways of responding, objective knowledge, subjective experience and specific situations that arise in his work, i.e. how he works, being in a given situation of working with a client and at the same time being a certain person with his own ways of behaving and responding, his direct subjective experience, as well as with certain professional capabilities (Smirnova, 2017: 5).

The experience of foreign countries shows that for successful work and further professional development a mediator needs to be accompanied by a colleague with extensive experience and qualifications.
A supervisor in the specialized field of mediation, within the framework of his job functions, must be able to identify problems in the practice of the supervised specialist, determine the main goals of supervision in a particular situation, propose and follow the proposed discussion format, correlate difficulties in the professional field with the skills necessary to solve them, analyse the actions of the supervised specialist, carry out mediation procedures and visual demonstration of professional skills, create visual problem-learning models, define goals and set goals for self-improvement, control the systematicity of self-study, and plan professional development. To do this, he needs knowledge of formal logic, theory and practice of mediation, supervision technology, the basics of time management, the basics of learning based on modelling, the basics of learning psychology, the system of advanced training in the field of mediation.

Thus, the professional standard contains three groups of generalized labour functions for positions: "General mediator," "Mediator in the specialized field," "Supervisor in the specialized field of mediation." The adoption of the professional standard allows us to conclude that mediation is recognized as an independent type of professional activity, and certainly contributes to its development.

\section{Ethical standards \\ of modern mediation practice in Russia}

The professional standard of a mediator indicates the need for mediators to know and comply with the Code of Professional Ethics of Mediators. It should be noted that currently there is no such unified code. Non-profit partnerships, chambers of commerce and industry, self-regulatory organizations of mediators develop their own Codes, which are mandatory only for members of these organizations. Thus, there is the Code of Professional Ethics of Mediators of the Non-Commercial Partnership "Alliance of Professional Mediators," the Code of Mediators of Russia (developed by the Non-Commercial Partnership Self-regulatory organization "National Organization of Mediators"), the Code of Ethics and Conduct of Mediators in Conciliation Procedures under 
the Union "Tula Chamber of Commerce and Industry," the Code of Professional Ethics of a Mediator of the Non-Commercial Partnership "League of Mediators," the Code of Professional Ethics of the Members of the Board of Mediators under the Public Organization "Union of Industrialists and Entrepreneurs of St. Petersburg," etc. This is due to the fact that mediation, in accordance with the legislation of the Russian Federation, is classified as a self-regulatory area, and in accordance with Art. 19 of the Federal Law "On an alternative procedure for resolving disputes with the participation of a mediator (mediation procedure)," clause 6 , the main functions of self-regulatory organizations of mediators include the development and approval of the rules of business and professional ethics of mediators, including the code of professional ethics. Since most of the mentioned Russian professional codes take the "European Code of Conduct for Mediators" as a basis, sharing its basic principles, it seems appropriate to take it as a basis for the analysis, as well as the Code of Mediators of Russia developed by the Self-regulatory organization Non-Commercial Partnership "National Organization of Mediators."

The European Code of Conduct for Mediators was developed by practicing mediators with the support of the European Commission and adopted at a conference in Brussels on June 2, 2004. The Code consists of four paragraphs within which certain standards are established. The first paragraph regulates the competence and function of a mediator. The principle of competence means that a mediator must have the necessary knowledge, appropriate education and regularly improve his qualifications, theoretical and practical skills. When accepting a proposal to resolve a dispute, the mediator must ensure that he has sufficient work experience and competence, and also provide all the necessary information about work experience and previous activities to the parties upon their request. Advertisements for mediator services must be truthful, professional and dignified. The second paragraph sets out the principles of independence and impartiality. Throughout the entire mediation process, the mediator must clarify the circumstances that may affect his independence or cause a conflict of interest; if such circumstances are found, the mediator is not entitled to continue the procedure. Such circumstances include: any personal or business relationship with one of the parties; any, whether direct or indirect, financial or other interest in the results of mediation, the previous activities of the mediator or someone from his company, enterprise in any capacity other than the mediator, in favour of one of the parties. The impartiality of the mediator is expressed not only in the fact that he acts objectively in relation to each of the parties, but also in the fact that he must be perceived as such by the parties themselves, strive for such a perception.

Paragraph three regulates the ethical standards for concluding an agreement to conduct mediation, dispute resolution and remuneration. Before starting the procedure, a mediator must make sure that the parties understand the essence of the mediator's procedure and the role of the mediator, the essential terms of the mediation agreement, as well as confidentiality, and that they agree to all these terms. The mediator must carry out the procedure properly, taking into account all its features. This paragraph establishes the principle of fairness of the procedure, which means that the mediator can, on his own initiative, terminate the mediation procedure if he considers that the agreement on the dispute will be unenforceable or illegal, or if he believes that the continuation of the procedure will not lead to a mediation agreement. The mediator should take all appropriate measures to ensure that mutual understanding is reached by all parties on the basis of advertent information and consent, and that all parties understand the terms of the agreement. The presence of the parties in the procedure is voluntary, and at any time they can refuse to continue it without giving reasons. Within the limits of his competence, the mediator, at the request of the parties, can inform the parties on how they can conclude an agreement and on the possibilities for ensuring it. The parties must be informed and agree with the procedure for remunerating the mediator. It is not allowed to start the mediation procedure without the consent of all parties interested on this issue. 
The final paragraph of the Code is devoted to confidentiality. All information received by the mediator during the mediation procedure, including the very fact of the mediation procedure or the possibility of carrying it out, is confidential. The mediator cannot provide the information he received from one of the parties to the other party, unless the consent of the first party is obtained or this must be done in accordance with the requirements of the law. An exception to the principle of confidentiality is when it is required by law or public policy.

The Code of Mediators in Russia follows the basic principles and standards developed by European colleagues, is established in accordance with international standards in the field of mediation and the legislation of the Russian Federation. The Code enshrines the following principles: a) impartiality and neutrality of a mediator; b) confidentiality; c) transparency and openness; d) acceptance, respect and support of the participants; e) responsibility; f) reliability; g) professional competence. Since the content of some of the principles has already been considered by us when characterizing the European Code of Conduct for Mediators, we consider it necessary to dwell on the content and procedure for implementing the principles of integrity, responsibility and the principle of professional competence. The principle of reliability means that during the preparation of the mediation procedure and during its implementation, the mediator must carefully observe all the established rules, principles and norms of conduct established by the Code of Mediators of Russia. The mediator must devote as much time, effort and attention to the mediation procedure as is required for the effective conduct of the procedure. The mediator follows the principle of "do no harm," in particular, avoids evaluative, rough, harsh judgments. The principle of responsibility reveals one of the main aspects of the procedure, where the mediator is responsible for organizing the process, the safety of the participants, and the parties themselves are responsible for the content of the procedure and the decision taken. The implementation of this principle requires certain efforts on the part of the mediator, since the parties often try to delegate their part of responsibility and transfer responsibility for the decision to the mediator. Professional competence means that a mediator agrees to conduct the mediation procedure only in cases for which he has the necessary qualifications and experience. If the mediator comes to the conclusion that his knowledge and experience is insufficient to resolve a specific dispute, he should inform the parties about it as soon as possible and discuss the possibility of continuing the procedure with his participation, replacing the mediator, if it is necessary, or to involve a co-mediator, assistant, specialist and/or experts in the relevant field. When carrying out the mediation procedure, the mediator cannot act as a consultant on legal, economic and other issues; he must explain to the parties the possibility of external consultation. Also, the mediator does not make proposals to the parties to resolve the dispute, except for the cases when the parties themselves ask the mediator for this, in such cases the mediator has the right to both refuse to make such a proposal and agree. If agreed, the mediator must inform the parties about the possible consequences of making such a proposal. The mediator needs to constantly improve his knowledge, skills and abilities, in particular, to participate in educational programmes for professional retraining, advanced training, educational programmes (workshops, seminars, courses, etc.). Similar to the European Code of Conduct for Mediators, the Code of Mediators of Russia regulates the issues of remuneration and advertising of mediators' services. The mediator, mediation service providers must provide the parties with full information about the remuneration, in particular about the amount and method of payment, except for cases when the mediator acts on a free basis or on a voluntary basis. The mediation procedure cannot be started without the explicit consent of the parties to the appropriate remuneration. The mediator's remuneration is formed taking into account all available factors, including the category and complexity of the dispute, the qualifications and experience of the mediator. We believe that taking into account the practice of providing mediation services on a free basis in our country, the parties should be informed about the funds that were used to pay for the 
mediator's services. When informing the society and potential users of mediation services about mediation, the mediator, mediation service providers, self-regulatory organizations of mediators must be truthful, not misleading about the essence of mediation, the role of the mediator, qualifications and experience of the mediator, services and remuneration. It is prohibited to provide information that could cause unreasonable expectations from the mediation procedure and the mediator. When informing about mediation, mediators avoid the statements that can directly or indirectly diminish the activities of other mediators, the value or authority of the judicial system. It should be noted that the Russian Code establishes the basis for the relationship between mediators, as well as between self-regulatory organizations of mediators and their members. Thus, in accordance with the code, mediators build relationships with each other based on mutual trust, respect, cooperation and support. Mediators refrain from actions and statements that may damage the honour, dignity, business reputation of another mediator and the institution of mediation as a whole. Mediators should not use unfair forms of competition, publicly belittle the competence and authority of other mediators. Each mediator, mediation service provider who has joined a self-regulatory organization of mediators has the right to count on: maintaining the moral principles of interaction in the community of mediators by the self-regulatory organization in order to maintain and increase confidence in their activities; on complying with the principles of fair competition; on protection of legitimate interests at any level, including the state; on the adequacy of the application of measures of influence to the members of the organization. Mediators should not take actions or commit acts aimed at discrediting self-regulatory organizations, at cultivating contradictions between self-regulatory organizations, at the threat of a conflict of interests of the organization members. Mediators, mediation service providers, self-regulatory organizations of mediators refrain from any action that may damage the reputation of the mediation community and the mediation institution as a whole. Self-regulatory organi- zations of mediators exercising control over the activities of mediators can use the provisions of the Code as a criterion for adhering to ethical and moral norms and principles of activities of persons engaged in mediation and mediation activities in any field. A comparative analysis of the codes of professional ethics adopted in Russia with the European Code of Conduct for Mediators demonstrates that the Russian professional community is not limited to the establishment of ethical standards in the "mediator-client" relationship, but also extends them to such relationships as "mediator-mediator," "mediator-professional community," "mediator-society."

\section{Problems of implementation of professional and ethical standards and control over their observance}

The federal law "On an alternative procedure for resolving disputes with the participation of a mediator (mediation procedure)" provides for the possibility of engaging in the activities of a mediator both on a professional and non-professional basis. The difference in the powers of a mediator working on an unprofessional basis and a mediator working on a professional basis seems to be minimal. Only professional mediators can resolve disputes that were previously referred to the court and advertise their activities. Taking into account the fact that mediation is positioned specifically as a pre-trial procedure for resolving disputes, questions arise about the guarantees of the quality of the service and about compliance with the standards of mediation. In this regard, we see it necessary to enshrine the principle of professionalism in the legislation on mediation, and to eliminate the norm on the possibility of carrying out the activities of a mediator on a non-professional basis. This will help to improve the quality of services provided and build confidence in the institution of mediation.

Considering the standards of professional activity and the practice of their implementation, it is necessary to examine such a category as professionalism, which is understood as the correspondence of knowledge, skills, as well as the entire value system of a person to the level of public expectations from this profes- 
sion, the quality of the social and professional environment. Professionalism characterizes person's personal and social capabilities, his ability to choose the optimal and appropriate ways of acting, it is based on high qualification and is also determined by the moral goal-setting of working activity (Tsyk, 2004). In our opinion, the criteria of professionalism and adherence to the professional activity standards should be assessed based on such factors as the mediator's special education; compliance of the mediator's activities with the qualification requirements; effectiveness of the mediator (a practice of successful dispute resolution); the mediator's adherence to the principles of ethics in the profession (Arkhipkina, Filatova, 2017: 75).

The basis for the compliance of the mediator's activities with professional standards, the formation of the necessary competencies, knowledge and skills is professional training. In modern conditions, one of the relevant problems is its quality. Initially, the training programme for mediators was established by the order of the Ministry of Education "On approval of the mediator training programme," ${ }^{3}$ which consisted of three educational programmes for advanced training: "Mediation. A basic course" (120), "Mediation. A training course for mediation trainers" (144 hours), "Mediation. Features of the application of the mediation procedure" (312 hours). It follows from the meaning of the programme that in order to say that a mediator carries out his activities on a professional basis, a listener must complete a full training course in all three modules within 5 years. Currently, the specified programme for the mediator training has lost its force in connection with the amendments made to the law "On Education." Educational organizations that train mediators independently develop their own programmes. It should be noted that many Russian universities have initiated master's programmes in mediation. However, in accordance with the professional standard of an expert in the field of mediation, completing a master's degree does not give the right to carry out the activities of a

\footnotetext{
3 On approval of the mediator training programme: Order of the Ministry of Education of February 14, 2011 No 187. In Rossiiskaia Gazeta, March, 23.
}

mediator on a professional basis, it is necessary to complete additional education programmes advanced training programmes in the field of mediation. In foreign countries, the issue of the quality of mediator training is regulated at the legislative level. Thus, paragraph 29 of the Austrian Law on Mediation in Civil Disputes establishes that the detailed procedure for obtaining education by mediators is determined by the Ministry of Justice. Not all organizations are allowed to train in mediation, but only registered ones. According to paragraph 23, the list of educational institutions and courses is managed by the Federal Minister of Justice. In order to register, an educational institution must submit an application indicating the content of the course, the staffing plan of employees and their qualifications, sources of funding for the course, and also provide evidence of a stable position. The Belgian Mediation Law adopted in 2005 provides for accreditation of organizations conducting training of mediators, training courses by the Federal Commission on Mediation (Shvarts). The need for official recognition of educational organizations in the field of mediation by the Netherlands Institute for Mediation is enshrined in the legislation of the Netherlands (Shvarts). In foreign law, the role of professional communities is great in establishing control over the quality of training of mediators, and their further accreditation. In Russia, self-regulatory organizations of mediators can also develop standards for the training of mediators.

Let us note that mediation in the social sphere, including education, is currently actively developing in Russia. Following the logic of the professional standard, the conduct of mediation procedures in educational institutions should be carried out by a person who meets the requirements for a mediator in a specialized field, however, at the present time we are moving towards using not the mediation procedure, but the method of school mediation, which makes it possible to reduce the requirements for a person settling a dispute before he has a document confirming the completion of training in the method of school mediation. In order to improve the quality of the mediator training, it is necessary to establish a unified education- 
al standard for the mediator training that includes theoretical and practical parts, and sets the duration of training. Due to the fact that mediation is an interdisciplinary field, and the training of mediators is carried out by higher educational institutions of various orientations, as well as by private educational organizations, it is necessary to determine a body responsible for the quality of the mediators' training. In addition, it is necessary to develop requirements for teachers of additional programmes in the field of mediation, since previously only persons trained under the programme "Mediation. A training course for coaches," which guaranteed the teacher's knowledge of the mediation procedure, the specifics of the mediation procedure in certain areas, the specifics of training specialists in the field of mediation.

When exercising control over the compliance of the mediator's activities with the qualification requirements; the effectiveness of the mediator's activities, his observance of the principles of professional ethics in foreign countries, several basic tools are used: certification of mediators by the state (Germany, the Netherlands), maintaining state registers of mediators (Austria), accreditation of mediators (Belgium). As for our country, there is no system of control over the training and activities of mediators.

In accordance with the legislation, mediation is classified as a self-regulatory area. Self-regulation is understood as an independent and proactive activity that is carried out by subjects of entrepreneurial or professional activity. Its content is the development and establishment of standards and rules for these activities, as well as control over compliance with these standards and rules. ${ }^{4}$ Thus, the quality of work of mediators - members of self-regulatory organizations (SRO), and their adherence to the principles of professional ethics should be monitored by the self-regulatory organizations of mediators. The State Register of Self-Regulatory Organizations of Mediators provides information on three self-regulatory organizations of mediators. Moreover, one of them has

\footnotetext{
4 On self-regulatory organizations: the Federal Law of December 1, 2012 No.315-FZ (2010). In Rossiiskaia Gazeta, December, 6
}

already been eliminated. Detailed information is provided only by the SRO Association "National Organization of Mediators." This organization provides a register of members of a self-regulatory organization. Members of the organization adhere to the Code of Mediators of Russia and the European Code of Conduct for Mediators. On the website of the partnership we can find the schedule of inspections of mediators - members of the Non-Commercial Partnership "National Organization of Mediators." According to the law, membership in a self-regulatory organization is voluntary, i.e. this is a right, not a duty of mediators, and in the legislation, professional standards there is no indication of membership in SROs for mediators as an admission to the implementation of mediation services. Hence, it can be concluded that mediators have no direct interest in being members of a self-regulatory organization, and be subject to additional control from its side, as well as bear the costs of paying membership and other fees. Membership in a self-regulatory organization will depend on the personal qualities of a mediator, his professional convictions, and is rather an image-building component. In general, the analysis of the development of legislation on mediation and the practice of its application allows us to conclude that the initially laid down concept of regulating relations in the field of mediation has not found its embodiment, in this regard, it is necessary to develop new approaches in the formation of a system for monitoring compliance with professional standards, professional ethics, the quality of mediators' training and the quality of mediation services provided.

\section{Conclusion}

After analysing the scientific literature on the problem under study, the main documents that establish the professional standards of the mediator's activity, the standards of professional ethics, as well as the practice of their implementation, the following conclusions can be made:

The professional standard "The expert in the field of mediation" establishes three groups of generalized labour functions for positions of a "General mediator," a "Mediator in a special- 
ized field," a "Supervisor in a specialized field of mediation." Thus, we are moving away from the usual triad: a "General mediator," a "Mediator in a specialized field," a "Mediator trainer," which followed from the mediator training programme that has been in effect since 2011. For each of the positions, the professional standard sets requirements for the level of knowledge, professional skills, and the level of education. The activity of a specialist in the field of mediation belongs to the highest (sixth and seventh) qualification levels. The professional standard sets high requirements for the level of education of a mediator - higher education, and for occupying such positions as "Mediator in a specialized field" and "Supervisor in a specialized field" only the specialist and master's degrees are enough. The adoption of the professional standard allows us to conclude that mediation is recognized as an independent type of professional activity, and certainly contributes to its development.

The professional ethics of a mediator, as a set of moral requirements for specialists in the field of mediation, should be an integral part of the training of mediators. It is necessary to develop a unified Code of Ethics for Russian mediators, which could act as a guideline both in training and for self-regulatory organizations of mediators. Currently, most of the mediators - members of self-regulatory organizations of mediators adhere to the European Code of Conduct for Mediators and the Code of Mediators of Russia, which establish the ethical foundations of the relationships "mediator-client," "mediator-mediator," "mediator-professional community," "mediator-society." At the same time, there are no guarantees of compliance with the codes of professional ethics by mediators who are not members of self-regulatory organizations. The main problems of implementing the standards of professional activity and professional ethics of mediators are based on the lack of uniform approaches in the train- ing of mediators, as well as educational standards, and the lack of a system for monitoring the quality of such training. In this connection, it seems necessary to develop an educational standard for the training of specialists in the field of mediation, the development of requirements for teachers who carry out training in the field of mediation, uniform requirements for the qualification examination. It is necessary to eliminate the existing discrepancy when graduates of master's programmes in the field of mediation cannot carry out their professional activities without additional training. Taking into account foreign experience, it seems expedient to establish an accreditation system for organizations that train mediators by self-regulating organizations of mediators, or by state bodies or institutions responsible for the development of mediation. Unfortunately, the analysis of documents regulating the professional activity of a specialist in the field of mediation demonstrates gaps in the professional trajectory, associated with the requirement to reach the age of 25 to carry out activities in the field of mediation, in connection with which it seems logical to introduce "intermediate" positions in the field of mediation, for example, the position of a "Mediator's assistant."

Since mediation is a self-regulatory field of activity, and the control over the observance of standards and rules is attributed to the main functions of self-regulatory organizations in the field of mediation, it is necessary to provide for legislative norms that stimulate mediators to become members of SROs. For example, this could be the provision that disputes referred to a court or an arbitration court in the future can only be settled by a mediator who is a member of a self-regulatory organization of mediators.

In conclusion, let us note that only compliance with all professional standards of activity, including compliance with the norms of professional ethics, allows a specialist to call himself a professional.

\section{References}

Allakhverdova, O.V. (2012). Obuchenie mediatorov i formirovanie kompetentsii [Training of mediators and the formation of competencies]. In Vestnik SPbGU [Bulletin of Saint-Petersburg State University], (3), 51-59. 
Arkhipkina, A.S., Filatova, U.B. (2017). Mediatsiia kak effektivnyi sposob uregulirovaniia sporov: problemy razvitiia i mekhanizmy vnedreniia [Mediation as an Effective Way to Resolve Disputes: Problems of Development and Implementation Mechanisms]. Irkutsk, ISU Publishing House, 109 p.

Evropeiskii kodeks povedeniia dlia mediatorov (2004). Available at: https://mediation-eurasia.pro/ wp-content/uploads/2018/04/evropejskij-kodeks-povedenija-dlja-mediatorov.pdf (accessed 9 August 2020).

Gaidaenko-Sher, N.I. (2017). Unifikatsiia trebovanii k kvalifikatsii mediatora: mediator i mediator v semeinykh sporakh [Unification of mediator qualification requirements: mediator and mediator in family disputes]. In Aktual'nye problemy rossiiskogo prava [Current problems of Russian law], 5(78), 56-60.

Iuridicheskaia konfliktologiia i mediatsiia. Available at: https://www.sfedu.ru/www/stat_pages22. show?p=ELS/inf/D\&x=ELS/10585 (accessed 9 July 2020).

Kodeks mediatorov Rossii (2012). Available at: http://files.sudrf.ru/2052/user/Docs/Kodeks_mediatorov.pdf (accessed 9 August 2020).

Korovianskii, D.G. (2018). Pravovye osobennosti podgotovki mediatorov v stranakh s anglosanksonskoi i romano-germanskoi pravovymi sem'iami [Legal features of mediators' training in countries with Anglo-Saxon and Romano-German legal families]. In Iuridicheskaia nauka [Legal science], (1), 144-153.

Kulakov, S.A (2004). Superviziia v psikhoterapii. Uchebnoe posobie dlia supervizorov i psikhoterapevtov [Supervision in psychotherapy. Tutorial for supervisors and psychotherapists]. Saint Petersburg, SPB, $196 \mathrm{p}$.

Natsional'naia organizatsiia mediatorov. Available at: www.npnom.ru (accessed 9 July 2020).

Rosreestr. Available at: www.rosreestr.ru (accessed 9 July 2020).

Smirnova, S.B (2017). Psikhologicheskaia superviziia: sbornik uchbno-metodichskikh materialov dlia spetsial'nosti 37.05.01 - Klinicheskaia psikhologiia [Psychological supervision: collection of educational materials for specialty 37.05.01 - Clinical psychology]. Blagoveshchensk, Amurskii gosudarstvennyi universitet, $79 \mathrm{p}$.

Shamlikashvili, Ts.A. (2017). Mediatsiia - sovremennyi metod vnesudebnogo razresheniia sporov [Mediation as a modern method of the extrajudicial dispute resolution]. Moscow, Mezhdunarodnyi tsentr upravlencheskogo i politicheskogo konsul'tirovaniia, $78 \mathrm{p}$.

Shvarts, O. Obzor zakonodatel'stva Bel'gii o mediatsii [Overview of Belgian legislation on mediation]. Available at: http://mediators.ru/rus/about_mediation/foreign_law/belgium/text1 (accessed 9 July 2020)

Shvarts, O. Mediatsiia v Niderlandakh [mediation in the Netherlands]. Available at: http://mediators. ru/rus/about_mediation/foreign_law/holland/text1 (accessed 9 July 2020).

Tsyk, V.A. (2004). Professionalizm: sotsial'no-filosofskii analiz [Professionalism: socio-philosophical analysis]. Available at: https://new-disser.ru/_avtoreferats/01002638350.pdf (accessed 9 July 2020).

Zagainova, S.K., Chudinovskaia, N.A., Sheremetova G.S. (2017). Obiazatel'naia mediatsiia v Italii: problemy realizatsii [Mandatory mediation in Italy: implementation problems]. In Elektronnoe prilozhenie k Rossiiskomu iuridicheskomu zhurnalu [Electronic supplement to the Russian juridical journal]. (6), 56-62.

Zakon Avsrii o mediatsii po grazhdanskim sporam (2003). Available at: www.mediatoren.justiz.gv.at/ mediatoren/mediatorenliste.nsf/docs/home (accessed 9 July 2020). 


\title{
Профессиональные и этические стандарты \\ в деятельности медиатора: \\ проблемы реализации и контроля
}

\author{
A.С.Архипкина \\ Восточно-Сибирский филиал Российского государственного \\ университета правосудия \\ Российская Федерация, Иркутск \\ Ассочиачия «Байкальская лига медиаторов» \\ Российская Федераиия, Иркутск
}

\begin{abstract}
Аннотация. В статье рассматриваются профессиональные и этические стандарты деятельности медиатора в России. Используя методы формального юридического анализа и сравнительно правовой метод, автор раскрывает требования, предъявляемые профессиональным стандартом к знаниям, навыкам и умениям медиатора, осуществляющего свою деятельность на профессиональной основе. Анализируются основные этические стандарты, закрепленные в Европейском кодексе поведения медиаторов, Кодексе российских медиаторов. Изложены основные проблемы реализации профессиональных и этических стандартов, а также контроля за их соблюдением. Приводится опыт зарубежных государств по установлению указанных стандартов и системы контроля.
\end{abstract}

Ключевые слова: медиация, профессиональный стандарт деятельности медиатора, кодекс профессиональной этики медиатора.

Научная специальность: 12.00.15 - гражданский процесс, арбитражный процесс. 